\title{
Optimal dietary linoleic acid to linolenic acid ratio improved fatty acid profile of the juvenile tambaqui (Colossoma macropomum)
}

\author{
Renan Rosa Paulino ${ }^{\mathrm{a}, *}$, Raquel Tatiane Pereira ${ }^{\mathrm{a}}$, Táfanie Valácio Fontes ${ }^{\mathrm{a}}$, Aires Oliva-Teles ${ }^{\mathrm{b}, \mathrm{d}}$, \\ Helena Peres ${ }^{\mathrm{b}, \mathrm{d}}$, Dalton José Carneiro ${ }^{\mathrm{c}}$, Priscila Vieira Rosa ${ }^{\mathrm{a}, * *}$ \\ a Departamento de Zootecnia, Universidade Federal de Lavras, UFLA, Lavras, MG, Brazil \\ ${ }^{\mathrm{b}}$ Departamento de Biologia, Faculdade de Ciências, Universidade do Porto, Porto, Portugal \\ ${ }^{\mathrm{c}}$ Departamento de Zootecnia, Faculdade de Ciências Agrárias e Veterinárias de Jaboticabal, Universidade Estadual Paulista Júlio de Mesquita Filho, Jabotical, SP, Brazil \\ d CIIMAR, Centro de Investigação Marinha e Ambiental, Terminal de Cruzeiros, Matosinhos, Portugal
}

\section{A R T I C L E I N F O}

\section{Keywords:}

Lipid nutrition

Essential fatty acids

Neotropical fish

EPA

DHA

ARA

\begin{abstract}
A B S T R A C T
The present study aimed to evaluate the effect of dietary linoleic acid to linolenic acid (LNA/ALA) ratio on growth performance, feed utilization, plasma metabolite profiles, and muscle and liver fatty acid profiles of juvenile tambaqui Colossoma macropomum. Six diets were formulated to contain incremental levels of corn oil (rich in LNA) from 0 to $7 \%$ at the expense of linseed oil (rich in ALA), resulting in dietary LNA/ALA ratios ranging from 3.1 to 26.9. A control diet including fish oil was also formulated. The trial lasted 49 days, and each diet was assigned to six groups of fish with an initial body weight of $43 \mathrm{~g}$. At the end of the trial, dietary LNA/ ALA ratio did not affect growth performance, feed utilization, and plasma metabolites profile, except for HDL that was lower in fish fed the 3.8 LNA/ALA diet than the 3.1 or 5.0 LNA/ALA diets. Whole-body protein content was lower in fish fed the control and 3.1 LNA/ALA diets. Composition of triglycerides, glucose and protein of liver and muscle was unaffected by dietary treatments. Eicosapentaeneoic acid (EPA, 20:5n-3) plus docosahexaenoic acid, (DHA, 22:6n-3) content of muscle decreased with the increase of LNA/ALA ratio. Fish fed 3.9-5.6 LNA/ALA diet showed the highest concentration of muscle ARA (arachidonic acid, 20:4n-6) and $\mathrm{EPA}+$ DHA among vegetable oil diets, though lower than that of fish fed the fish oil based diet. In conclusion, dietary LNA/ALA ratio should range between 3.9-5.6 to produce fillets with high EPA, DHA, and ARA contents, thus improving the nutritional quality of tambaqui fillets for human consumers.
\end{abstract}

\section{Introduction}

Fish, like other vertebrates, cannot synthesize de novo n-3 or n-6 series of C18-polyunsaturated fatty acids (PUFA), such as $\alpha$-linolenic acid (ALA, 18:3n-3) and linoleic acid (LNA, 18:2n-6), and consequently require a dietary supply of these essential fatty acids (EFA) (Henderson and Tocher, 1987; Sargent et al., 2002). Dietary C18-PUFA are then converted by the animals into the biologically active long-chain polyunsaturated fatty acids (LC-PUFA), namely, eicosapentaenoic acid (EPA, 20:5n-3), docosahexaenoic acid (DHA, 22:6n-3), and arachidonic acid (ARA, 20:4n-6). The efficiency of conversion depends upon the presence and expression of fatty acid (FA) desaturation and elongation genes (Tocher and Glencross, 2015). Contrary to marine fish that require a dietary source of LC-PUFA, tropical freshwater species can convert the C18 PUFA into the LC-PUFA, and EFA requirements can be satisfied generally by LNA and ALA at around $1.0 \%$ of the diet dry weight (Tocher, 2010; Tocher and Glencross, 2015). Due to the importance of n-3 LC-PUFA (EPA and DHA) on human health and wellbeing (Calder, 2014), the rate of this bioconversion is of paramount importance in determining the final nutritional quality of aquaculture products. The recommendations for consumption of EPA + DHA are normally between 200 and $600 \mathrm{mg}$ per person per day (Harris et al., 2009), and fish are usually the primary source of these fatty acids (FA).

The extension of bioconversion of PUFA into LC-PUFA may be modulated by the dietary FA profile. The same elongase and desaturase enzymes are active for the bioconversion of FA of the n-3, n-6, and n-9 series, but due to competition between $n-3$ and n-6 PUFA, a dietary excess of LNA may depress metabolism of ALA, and vice versa (Bell and Koppe, 2010). Therefore, the conversion of ALA to n-3 LC-PUFA may be profoundly affected by the dietary supply of LNA (Tocher and Glencross, 2015), and an optimum dietary balance of LNA/ALA is required to maximize n-3 LC-PUFA synthesis.

\footnotetext{
* Corresponding author.

** Correspondence to: P.V. Rosa, Departamento de Zootecnia, Universidade Federal de Lavras s/n, P.O. Box 3.037, 37200-000 Lavras, Minas Gerais, Brazil.

E-mail addresses: renanrpaulino@ufu.br (R.R. Paulino), priscila@dzo.ufla.br (P.V. Rosa).
} 
Studies in fish demonstrated that different LNA/ALA ratios influenced growth performance of yellow catfish (Pelteobagrus fulvidraco) (Tan et al., 2009), FA metabolism of rainbow trout (Thanuthong et al., 2011) and Murray cod (Senadheera et al., 2010), immune response of juvenile grouper (Wu and Chen, 2012), reproduction of the Japanese eel (Furuita et al., 2007), tissue FA deposition of Cyprinus carpio (Tian et al., 2016), and immunity and absorptive capacities of intestine mucosa of grass carp (Ctenopharyngodon idella) (Zeng et al., 2015; Zeng et al., 2016).

The use of dietary alternatives to FO is becoming more common in aquafeeds and alternative lipid sources are being incorporated at higher levels in fish diets as global FO supplies are becoming more costly and less available worldwide (Sprague et al., 2016). The use of VO usually decrease the concentration of beneficial n-3 LC-PUFA in fish fillets destined for the human consumer (Tocher and Glencross, 2015). Thus, it is of great importance to evaluate the effects of dietary lipid sources and FA profiles on fillet quality.

Tambaqui (Colossoma macropomum) is an omnivorous freshwater fish of increasing interest in Latin America aquaculture. Tambaqui accepts plant feedstuffs-based diets devoid of any animal feedstuff supplements (van der Meer et al., 1996). Except for dietary protein and lipid recommendations, nutrient requirements of this species are still poorly studied. van der Meer et al. (1995) obtained the best growth performance of $1.5 \mathrm{~g}$ fish when fed diets with $50 \%$ protein, while for $50 \mathrm{~g}$ and $125 \mathrm{~g}$ fish dietary protein needs were met with a diet including $30 \%$ protein. Later, van der Meer et al. (1997) observed better performance of $1.1 \mathrm{~g}$ fish when fed diets with $40 \%$ protein instead of $30 \%$ protein. Moreover, although dietary lipid levels (5 to 20\%) did not affect growth performance, feed conversion was better with dietary lipids of 15-20\%. Recently, de Almeida et al. (2011) observed similar performances of $123-130 \mathrm{~g}$ fish fed diets with $30 \%$ protein and $8 \%$ lipids or $35 \%$ protein and $4.9 \%$ lipids. The nutritional requirements of LNA and ALA or the optimum dietary $n-6 / n-3$ ratio are not yet known. Therefore, the present study aimed to evaluate the effect of dietary LNA/ALA ratio on growth performance, carcass composition, plasma lipoproteins, and FA profiles of muscle and liver of tambaqui juveniles.

\section{Material and methods}

\subsection{Experimental diets}

Six isoproteic (36\% protein) and isolipid ( $8 \%$ lipids) diets were formulated to have $n-6 / n-3$ ratio ranging from 3.1 to 26.9 , by manipulating vegetable oils (VO) source (linseed, corn, and palm oils). A control diet was also formulated similar to the other diets but including fish oil (FO) instead of vegetable oils. The diets were manufactured at the Laboratory of Aquaculture (LAQUA) of the Federal University of Minas Gerais, UFMG. Dietary ingredients were ground, weighed, mixed in a paddle mixer (Inbramaq ${ }^{\oplus}$, São Paulo, Brazil), extruded in a singlescreen extruder (Inbramaq ${ }^{\circledR}$, São Paulo, Brazil) to form $4 \mathrm{~mm}$ pellets, and dried for $12 \mathrm{~h}$ in an oven at $50^{\circ} \mathrm{C}$. The oil was incorporated to the dried pellets by manual spraying. Ingredient composition and proximate analyses of the diets are shown in Table 1, and FA composition of the diets is presented in Table 2.

\subsection{Growth trial}

The experiment was conducted according to the Ethics Committee of Animal Welfare of the Federal University of Lavras, protocol number $036 / 2015$. The trial was conducted at the Fish Laboratory, Federal University of Lavras, UFLA Brazil, and the experimental facilities consisted of an indoor thermoregulated recirculation water system, equipped with 42 fiberglass tanks (100-litre capacity each) supplied with continues flow of aerated, filtered (sand filter and biofilters) and ultraviolet sterilized water. During the trial, water quality was monitored daily and maintained within the optimal conditions for
Table 1

Composition and proximate analyses of the experimental diets.

\begin{tabular}{|c|c|c|c|c|c|c|c|}
\hline & \multirow[t]{2}{*}{ Control } & \multicolumn{6}{|c|}{ Dietary LNA/ALA ratio } \\
\hline & & 3.1 & 3.8 & 5.0 & 7.2 & 12.0 & 26.9 \\
\hline \multicolumn{8}{|c|}{ Ingredients ( $\%$ dry weight) } \\
\hline Soybean meal ${ }^{\mathrm{a}}$ & 37 & 37 & 37 & 37 & 37 & 37 & 37 \\
\hline Corn meal $^{\mathrm{b}}$ & 22.2 & 22.2 & 22.2 & 22.2 & 22.2 & 22.2 & 22.2 \\
\hline $\begin{array}{l}\text { Soy protein } \\
\text { concentrate }^{c}\end{array}$ & 15 & 15 & 15 & 15 & 15 & 15 & 15 \\
\hline Wheat flour ${ }^{\mathrm{d}}$ & 10 & 10 & 10 & 10 & 10 & 10 & 10 \\
\hline Fish oil ${ }^{\mathrm{e}}$ & 7.0 & - & - & - & - & - & - \\
\hline Linseed oil $^{\mathrm{f}}$ & - & 6.3 & 5.0 & 3.8 & 2.5 & 1.3 & - \\
\hline Corn oil $^{\mathrm{f}}$ & - & - & 1.4 & 2.8 & 4.2 & 5.6 & 7.0 \\
\hline Palm oil ${ }^{\mathrm{f}}$ & - & 0.7 & 0.6 & 0.4 & 0.3 & 0.1 & - \\
\hline Yeast $^{g}$ & 5 & 5 & 5 & 5 & 5 & 5 & 5 \\
\hline Dicalcium phosphate $^{\text {h }}$ & 1.5 & 1.5 & 1.5 & 1.5 & 1.5 & 1.5 & 1.5 \\
\hline $\begin{array}{l}\text { Mineral and vitamin } \\
\operatorname{mix}^{i}\end{array}$ & 1 & 1 & 1 & 1 & 1 & 1 & 1 \\
\hline L-Lysine $\mathrm{HCl}^{\mathrm{j}}$ & 0.6 & 0.6 & 0.6 & 0.6 & 0.6 & 0.6 & 0.6 \\
\hline DL-methionine $^{k}$ & 0.4 & 0.4 & 0.4 & 0.4 & 0.4 & 0.4 & 0.4 \\
\hline L-threonine ${ }^{j}$ & 0.2 & 0.2 & 0.2 & 0.2 & 0.2 & 0.2 & 0.2 \\
\hline Antioxidant BHT & 0.1 & 0.1 & 0.1 & 0.1 & 0.1 & 0.1 & 0.1 \\
\hline \multicolumn{8}{|c|}{ Proximate composition $\left(\mathrm{mg} \mathrm{g}^{-1}\right)$} \\
\hline Dry matter & 908.7 & 913.1 & 907.7 & 905.7 & 911.3 & 911.0 & 910.9 \\
\hline Crude protein & 361.7 & 358.9 & 360.0 & 361.6 & 360.7 & 354.2 & 364.9 \\
\hline Crude lipid & 79.2 & 80.7 & 69.9 & 71.2 & 71.7 & 73.6 & 80.4 \\
\hline Ash & 57.0 & 55.8 & 56.6 & 56.4 & 55.9 & 58.1 & 58.6 \\
\hline Energy $(\mathrm{MJ} / \mathrm{kg})$ & 20.9 & 20.3 & 21.0 & 20.6 & 20.3 & 19.9 & 20.7 \\
\hline
\end{tabular}

a Crude protein $46 \%$, crude lipids $3 \%$, dry matter $12.5 \%$ Cargill, SP, Brazil.

b Crude protein 7.9\%, crude lipids 3\%, dry matter 13.9\% Bioquima, MG, Brazil.

c Crude protein $60 \%$, crude lipids $1.8 \%$, dry matter $12.5 \%$ Cargill, SP, Brazil.

${ }^{\mathrm{d}}$ Crude protein $14 \%$, crude fiber $11 \%$, lipids $3 \%$, dry matter $13.5 \%$ Bioquima, MG, Brazil.

e Refined oil total Alimentos, MG, Brazil.

${ }^{\mathrm{f}}$ Refined oil Mundo dos Óleos, DF, Brazil.

${ }^{\mathrm{g}}$ From Saccharomyces cerevisiae Grupo Ullmann, MG, Brazil.

${ }^{\mathrm{h}}$ Nutrimix, MS, Brazil.

${ }^{\mathrm{i}} \mathrm{Mix}$ vita/min omnivorous fish Cargill, SP, Brazil. Composition ( $\mathrm{mg} \mathrm{kg}^{-1}$ diet): iron sulfate, 196; copper sulfate, 28; zinc oxide, 280; manganese oxide, 52; sodium selenite, 1.2; cobalt sulfate, 0.4 ; potassium iodide, 1.2 ; vitamin A, 19,950 ( $\mathrm{UI} \mathrm{kg}^{-1}$ diet); vitamin D3, 7980 (UI kg ${ }^{-1}$ diet); vitamin E, 199; vitamin K3, 10; vitamin C, 700; thiamin, 50; riboflavin, 50; pyridoxine, 50; cyanocobalamin, 0.1; niacin, 200; calcium pantothenate, 100; folic acid, 10; biotin, 1.6; inositol, 100; ethoxyquin, 247.

j Ajinomoto, SP, Brazil.

${ }^{\mathrm{k}}$ Evonik, SP, Brazil.

Tambaqui; dissolved oxygen averaged $3.7 \pm 0.6 \mathrm{mg} / \mathrm{L}$, total ammonia $0.24 \pm 0.20 \mathrm{ppm}, \mathrm{pH} 6.31 \pm 0.32$ and temperature $28.0 \pm 0.41{ }^{\circ} \mathrm{C}$.

Tambaqui juveniles were obtained from Centro de Aquicultura da Universidade Estadual Paulista (UNESP) and acclimated to the rearing conditions for 15 days. Then, 10 fish with $42 \mathrm{~g}$ mean initial weight were randomly distributed to each tank and each experimental diet was randomly assigned to six groups. The experiment lasted 49 days and the fish were hand-fed twice a day to apparent visual satiation.

At the end of the feeding trial, fish were counted and weighed after being unfed for $24 \mathrm{~h}$ and two fish per tank were randomly sampled. Blood was obtained from the caudal vein with heparinized needles and plasma recovered after centrifugation at $1000 \mathrm{~g}$ for $10 \mathrm{~min}$ and stored at $-80^{\circ} \mathrm{C}$ until analysis. Thereafter, fish were killed by overdose of 2 phenoxyethanol (1:500 v/v, Fluka; Sigma-Aldrich, Madrid, Spain) and rinsed in distilled water to remove residual anesthetic. Fish length and weight, and viscera and liver weights were recorded for determination of condition factor (CF), hepatosomatic index (HSI) and viscerosomatic index (VSI). Liver and dorsal white muscle of these fish were collected and stored at $-80^{\circ} \mathrm{C}$ until analyses.

\subsection{Analytical methods}

Chemical composition of ingredients, diets, and carcass were 
Table 2

Fatty acid composition $\left(\mathrm{mg} \mathrm{g}^{-1}\right)$ of the experimental diets.

\begin{tabular}{|c|c|c|c|c|c|c|c|}
\hline & \multirow[t]{2}{*}{ Control } & \multicolumn{6}{|c|}{ Dietary LNA/ALA ratio } \\
\hline & & 3.1 & 3.8 & 5.0 & 7.2 & 12.0 & 26.9 \\
\hline 14:0 & 35.1 & 1.6 & 1.3 & 0.9 & 1.3 & 1.0 & 0.4 \\
\hline $16: 0$ & 212.0 & 126.4 & 125.1 & 125.7 & 126.9 & 126.1 & 127.0 \\
\hline $16: 1$ & 46.5 & 1.9 & 1.9 & 2.0 & 2.5 & 2.2 & 2.3 \\
\hline $17: 0$ & 5.5 & 0.6 & 0.7 & 0.7 & 0.7 & 0.6 & 0.6 \\
\hline 18:0 & 48.8 & 38.3 & 35.2 & 30.8 & 29.4 & 26.4 & 23.8 \\
\hline $18: 1 n-9$ & 226.9 & 254.5 & 272.4 & 285.4 & 300.7 & 314.3 & 326.2 \\
\hline 18:2n-6 LNA & 166.5 & 420.4 & 430.6 & 443.9 & 453.7 & 467.5 & 483.1 \\
\hline $18: 3 n-6$ & 1.2 & 1.0 & 0.9 & 0.8 & 0.0 & 0.0 & 0.0 \\
\hline 18:3n-3 ALA & 16.0 & 133.5 & 111.9 & 89.1 & 62.8 & 38.9 & 17.9 \\
\hline $20: 0$ & 3.4 & 3.1 & 3.7 & 3.9 & 4.3 & 4.5 & 4.4 \\
\hline $20: 1$ & 7.5 & 2.2 & 2.2 & 2.1 & 2.2 & 2.1 & 2.1 \\
\hline $20: 4 n-6$ ARA & 10.4 & - & - & - & - & - & - \\
\hline 20:5n-3 EPA & 50.6 & - & - & - & - & - & - \\
\hline $22: 0$ & 2.5 & 3.2 & 3.0 & 2.8 & 2.4 & 2.2 & 1.9 \\
\hline $22: 6 n-3$ DHA & 80.8 & - & - & - & - & - & - \\
\hline $24: 0$ & 1.2 & 1.6 & 1.7 & 1.8 & 1.9 & 2.0 & 1.9 \\
\hline$\Sigma$ SAFA & 325.7 & 175.2 & 170.9 & 167.0 & 167.2 & 162.8 & 160.0 \\
\hline$\Sigma$ MUFA & 286.1 & 258.6 & 431.7 & 444.9 & 453.7 & 468.0 & 483.1 \\
\hline$\Sigma$ PUFA & 328.4 & 554.9 & 543.4 & 533.8 & 517.3 & 506.9 & 501.0 \\
\hline$\sum \mathrm{n}-6$ & 169.0 & 421.4 & 431.7 & 444.9 & 453.7 & 468.0 & 483.1 \\
\hline$\sum \mathrm{n}-3$ & 67.4 & 133.5 & 111.9 & 89.1 & 63.3 & 38.9 & 17.9 \\
\hline LNA/ALA & 10.4 & 3.1 & 3.8 & 5.0 & 7.2 & 12.0 & 26.9 \\
\hline
\end{tabular}

Palm oil was added to the total lipid content to adjust saturated fatty acids on Linseed oil treatment. $\Sigma$ SAFA: sum of saturated fatty acids; $\Sigma$ MUFA: sum of monounsaturated fatty acids; $\Sigma$ PUFA: sum of polyunsaturated fatty acids.

analyzed according to AOAC methods (AOAC, 2005). Briefly, moisture was determined after drying in an oven at $105^{\circ} \mathrm{C}$ for $24 \mathrm{~h}$; ash by incineration in a muffle furnace at $550{ }^{\circ} \mathrm{C}$ for $24 \mathrm{~h}$; crude lipid by petroleum ether extraction in a Soxtec System; crude protein (N6.25) by the Kjeldahl method after acid digestion using a Kjeldahl System. Gross energy of diets was determined by direct combustion in an adiabatic bomb calorimeter.

Total protein in blood was quantified by refractometer and blood glucose was analyzed using a digital glucometer (Accu-Check ${ }^{\circledR}$ Performa, Roche, Brazil). Commercial kits (Labtest Diagnóstica SA) were used to quantify Triglycerides (TAG) (Triglycerides Liquiform, Cat. 87), cholesterol (Cholesterol Liquiform, Cat. 76), HDL-cholesterol (HDL LE, Cat. 98), and LDL-cholesterol (LDL Liquiform, Cat. 111) in plasma. All analyses were done in triplicate in 96-well plates and absorbance read in a spectrophotometer (Multiskan GO, Thermo Scientific, USA).

White muscle and liver samples were homogenized in ice-cold deionized water, centrifuged $\left(13,400 \times g, 10 \mathrm{~min} ; 4^{\circ} \mathrm{C}\right)$ and the resultant supernatant stored at $-80^{\circ} \mathrm{C}$ until used. Glucose and triglyceride were measured by commercial kits (Glucose HK Liquiform, Cat. 85 and Triglycerides Liquiform, Cat. 87) and soluble protein content was determined according to Bradford (1976), using bovine serum albumin solution as a standard.

FA profile of diets, liver and muscle were analyzed according to Araújo et al. (2017). Briefly, total lipid was extracted according to Folch et al. (1957), with slight modification. FA profile was determined using a GC2010 gas chromatograph (GC) (Shimadzu, Kyoto, Japan) equipped with a flame ionization detector (FID) and a SP-2560 fused silica capillary column (100.0 m $90.25 \mathrm{~mm}, 0.20 \mathrm{~lm}$ film; Supelco, Sigma-Aldrich, St. Louis, MO, USA). FA peaks were integrated using GC solution chromatography software (version 4.02), and peaks were identified by comparison to known standards (37 Component FAME Mix; Supelco, Sigma-Aldrich). Total lipids of fillet were used to express the amount of EPA, DHA, and EPA + DHA in $100 \mathrm{~g}$ of fillet.

\subsection{Statistical analysis}

Data is presented as mean \pm pooled standard error of the mean. Data analysis was done by one-way analysis of variance (ANOVA) after testing for normality and homogeneity of variances with Shapiro-Wilk and Levene tests, respectively. Significant differences among means were determined by the Tukey HSD test. Data, excluding the control, was also subjected to regression analysis (linear, quadratic and piecewise), with dietary LNA/ALA level as the independent variable. A probability level of 0.05 was used for rejection of the null hypothesis. Statistical analyses was done using IBM SPSS Statistics for Windows, Version 23.0 (Armonk, NY, USA).

\section{Results}

Data on growth performance and feed efficiency is presented in Table 3. Overall mortality was low and it was not affected by dietary treatments. Growth was also not affected by diet composition. Daily growth index (DGI) ranged between 3.3 and 3.5\% and weight gain

Table 3

Growth performance, feed utilization, condition factor, hepatosomatic and visceral indices of juvenile tambaqui fed the experimental diets for 7 weeks.

\begin{tabular}{|c|c|c|c|c|c|c|c|c|c|c|c|c|c|}
\hline & \multirow[t]{2}{*}{ Control } & \multicolumn{6}{|c|}{ Dietary LNA/ALA ratio } & \multirow[t]{2}{*}{ SEM } & \multirow[t]{2}{*}{$P$-value } & \multicolumn{4}{|c|}{ Regression $\left(\mathrm{P}, \mathrm{r}^{2}\right)$} \\
\hline & & 3.1 & 3.8 & 5.0 & 7.2 & 12.0 & 26.9 & & & Linear & & Quadra & \\
\hline Initial body weight (g) & 43.0 & 42.9 & 43.1 & 42.9 & 42.9 & 42.8 & 42.5 & 0.1 & .695 & 0.007 & 0.866 & 0.049 & 0.866 \\
\hline Final body weight $(\mathrm{g})$ & 144.7 & 141.7 & 139.4 & 134.1 & 135.4 & 133.7 & 135.5 & 2.8 & .675 & 0.407 & 0.176 & 0.215 & 0.641 \\
\hline Weight gain $\left(\mathrm{g} \mathrm{kg} \mathrm{ABW}^{-1} \mathrm{day}^{-1}\right)$ & 21.9 & 21.7 & 21.4 & 20.9 & 21.0 & 20.9 & 21.1 & 0.3 & .858 & 0.507 & 0.117 & 0.261 & 0.592 \\
\hline Daily growth index $(\%)^{1}$ & 3.5 & 3.5 & 3.4 & 3.3 & 3.3 & 3.3 & 3.3 & 0.1 & .789 & 0.312 & 0.251 & 0.268 & 0.585 \\
\hline Feed intake $\left(\mathrm{g} \mathrm{kg} \mathrm{ABW}^{-1} \mathrm{day}^{-1}\right)$ & $23.4^{\mathrm{ab}}$ & $23.4^{\mathrm{b}}$ & $23.3^{\mathrm{ab}}$ & $22.8^{\mathrm{ab}}$ & $22.0^{\mathrm{a}}$ & $23.3^{\mathrm{ab}}$ & $23.3^{\mathrm{ab}}$ & 0.2 & .038 & 0.703 & 0.040 & 0.789 & 0.146 \\
\hline Feed efficiency ${ }^{2}$ & 0.9 & 0.9 & 0.9 & 0.9 & 1.0 & 0.9 & 0.9 & 0.0 & .370 & 0.800 & 0.018 & 0.823 & 0.122 \\
\hline Protein efficiency ratio ${ }^{3}$ & 2.6 & 2.6 & 2.5 & 2.5 & 2.6 & 2.5 & 2.5 & 0.0 & .215 & 0.449 & 0.149 & 0.771 & 0.159 \\
\hline Survival & 97 & 98 & 100 & 98 & 100 & 97 & 100 & 0.0 & .617 & 0.620 & 0.067 & 0.623 & 0.271 \\
\hline Condition Factor ${ }^{4}$ & 3.3 & 3.5 & 3.3 & 3.3 & 3.4 & 3.3 & 3.2 & 0.0 & .404 & 0.119 & 0.494 & 0.351 & 0.502 \\
\hline $\mathrm{HSI}^{5}$ & 2.2 & 2.3 & 2.1 & 2.1 & 2.1 & 2.1 & 2.1 & 0.0 & .141 & 0.490 & 0.126 & 0.555 & 0.325 \\
\hline $\mathrm{VSI}^{6}$ & 6.3 & 6.9 & 6.5 & 6.3 & 6.3 & 6.6 & 6.5 & 0.1 & .212 & 0.859 & 0.009 & 0.879 & 0.082 \\
\hline
\end{tabular}

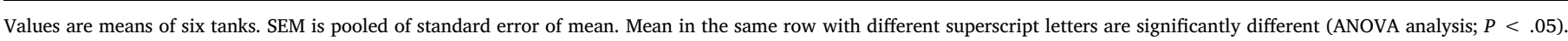
Regression analysis excluded the control diet.

Average body weight (ABW): (initial body weight + final body weight) $/ 2$.

${ }^{1}$ DGI: ((final body weight ${ }^{1 / 3}-$ initial body weight ${ }^{1 / 3}$ ) $/$ time in days $) \times 100$.

${ }^{2} \mathrm{FE}$ : (wet weight gain / dry feed intake).

${ }^{3}$ PER: (wet weight gain / dry crude protein intake).

${ }^{4}$ CF: $100 \times$ (body weight; g) / (body length; cm) ${ }^{3}$.

${ }^{5}$ Hepatosomatic index: (liver weight / body weight) $\times 100$.

${ }^{6}$ Visceral index: (viscera weight $/$ body weight) $\times 100$. 
Table 4

Whole-body, liver and white muscle ( $\mathrm{mg} \mathrm{g}^{-1}$ of dry weight) composition of juvenile Tambaqui fed the experimental diets for 7 weeks.

\begin{tabular}{|c|c|c|c|c|c|c|c|c|c|c|c|c|c|}
\hline & \multirow[t]{2}{*}{ Control } & \multicolumn{6}{|c|}{ Dietary LNA/ALA ratio } & \multirow[t]{2}{*}{ SEM } & \multirow[t]{2}{*}{$P$-value } & \multicolumn{4}{|c|}{ Regression $\left(\mathrm{P}, \mathrm{r}^{2}\right)$} \\
\hline & & 3.1 & 3.8 & 5.0 & 7.2 & 12.0 & 26.9 & & & Linear & & Quadra & \\
\hline Moisture & $700.7^{b}$ & $694.6^{\mathrm{ab}}$ & $681.4^{\mathrm{ab}}$ & $675.7^{\mathrm{a}}$ & $688.6^{\mathrm{ab}}$ & $695.5^{\mathrm{ab}}$ & $683.7^{\mathrm{ab}}$ & 2.2 & .029 & 0.979 & 0.000 & 0.768 & 0.161 \\
\hline Lipid & 301.8 & 293.3 & 308.1 & 296.1 & 303.4 & 295.4 & 313.4 & 3.6 & .748 & 0.186 & 0.389 & 0.353 & 0.500 \\
\hline Protein & $606.2^{\mathrm{b}}$ & $609.4^{\mathrm{b}}$ & $657.0^{\mathrm{a}}$ & $656.5^{\mathrm{a}}$ & $659.3^{\mathrm{a}}$ & $670.1^{\mathrm{a}}$ & $656.3^{\mathrm{a}}$ & 4.7 & .000 & 0.510 & 0.116 & 0.323 & 0.529 \\
\hline Ash & 126.9 & 129.6 & 130.0 & 128.5 & 126.3 & 128.0 & 131.1 & 1.1 & .915 & 0.394 & 0.185 & 0.158 & 0.707 \\
\hline \multicolumn{14}{|c|}{ Liver composition } \\
\hline Triglycerides & 14.4 & 14.2 & 13.7 & 13.8 & 12.9 & 14.1 & 13.3 & 0.3 & .934 & 0.521 & 0.110 & 0.838 & 0.111 \\
\hline Glucose & 15.3 & 15.6 & 14.0 & 12.7 & 12.9 & 14.6 & 15.7 & 0.5 & .380 & 0.302 & 0.259 & 0.497 & 0.372 \\
\hline Protein & 123.2 & 114.4 & 103.7 & 109.6 & 109.4 & 102.6 & 114.8 & 2.2 & .158 & 0.524 & 0.108 & 0.331 & 0.521 \\
\hline \multicolumn{14}{|c|}{ Muscle composition } \\
\hline Triglycerides & 1.0 & 1.1 & 1.2 & 1.3 & 1.2 & 1.0 & 1.1 & 0.0 & .390 & 0.617 & 0.068 & 0.630 & 0.265 \\
\hline Glucose & $0.8^{\mathrm{ab}}$ & $0.9^{\mathrm{b}}$ & $0.8^{\mathrm{ab}}$ & $1.0 \mathrm{~b}$ & $1.0^{\mathrm{b}}$ & $1.0^{\mathrm{b}}$ & $0.6^{\mathrm{a}}$ & 0.0 & .000 & 0.167 & 0.416 & 0.068 & 0.833 \\
\hline Protein & 42.8 & 39.9 & 43.3 & 45.8 & 50.2 & 48.6 & 45.9 & 1.6 & .633 & 0.563 & 0.090 & 0.158 & 0.708 \\
\hline
\end{tabular}

Values are means of six tanks. SEM is pooled of standard error of mean.

Mean in the same row with different letters are significantly different (ANOVA analysis; $P<.05$ ). Regression analysis excluded the control diet.

averaged $21 \mathrm{~g} \mathrm{~kg} \mathrm{ABW}^{-1} \mathrm{day}^{-1}$. Feed intake was similar among groups, though it was lower in fish fed 7.2 than 3.1 LNA/ALA diets. Nonetheless, FE and PER were identical in all groups.

CF, HSI and VSI were not affected by dietary treatments (Table 3). At the end of the trial, moisture content of fish fed the control diet was higher than in fish fed the 5.0 LNA/ALA and whole-body protein content of fish the control and 3.1 LNA/ALA ratio diets was lower than in the other groups (Table 4). No differences among groups were noticed in liver and muscle composition, except for muscle glucose that was lower in fish fed diet 26.9 LNA/ALA than diets 3.1, 5.0, 7.4 and 12.0 LNA/ALA (Table 4).

Plasma cholesterol, triglycerides, LDL and protein were not affected by diet treatment (Table 5). Plasma HDL was lower in fish fed diet 3.8 LNA/ALA than diets 3.1 and 5.0 LNA/ALA, and plasma glucose was higher in fish fed diet 7.2 LNA/ALA than the control and 3.1 LNA/ALA diets.

Liver total fatty acids profile of fish fed the FO-based (control diet) showed the highest hepatic content of EPA, DHA and total n-3, and the lowest $n-6 / n-3$ ratio (Table 6). Among fish fed the VO based diets, hepatic EPA and DHA content linearly decreased with the increase of dietary LNA/ALA ratio; while a quadratic model adjusted better the hepatic ARA content. The optimal dietary LNA/ALA ratio for maximal ARA deposition in the liver was estimated to be 18.6. Consequently, total hepatic PUFA and LC-PUFA in fish fed the VO diets linearly decreased with the increase of dietary LNA/ALA ratio.

Muscle of fish fed the FO-based diet also presented the highest contents of EPA, DHA and total $n-3$ and the lowest $n-6 / n-3$ ratio (Table 7). Among fish fed the VO diets, muscle ALA, DHA, EPA and total $n-3$ contents linearly decreased and LNA/ALA ratio linearly increased with the increase of dietary LNA/ALA. Furthermore, muscle EPA content linearly decreased with the increase of LNA/ALA ratio up to 9.6 and then stabilized (piecewise linear regression analysis; $r=0.99)$. No differences were observed in muscle LNA and total $n-6$ FA contents among fish fed the VO diets.

Expressed in mg per $100 \mathrm{~g}$ of muscle, the amount of EPA, DHA and EPA + DHA were also higher in fish fed the control FO-based diet than the vegetable oil diets (Fig. 1). Among fish fed the VO diets, muscle EPA level decreased as the LNA/ALA ratio increased, while muscle DHA and EPA + DHA increased up to a dietary LNA/ALA of 3.8-5, then decreased to a minimum value in fish fed diet 26.9 LNA/ALA.

The recommendation of fillet consumption to obtain $200 \mathrm{mg}$ of EPA + DHA (1.4 g per week) is shown in Fig. 2. In fish fed the FO-based diet this value is obtained with the consumption of circa $400 \mathrm{~g}$ fillets, while with the VO-based diets $1.3-4.0 \mathrm{~kg}$ of fillet would be needed, with the lowest fillet consumption being achieved with circa of 5.0 LNA/ALA diet.

\section{Discussion}

Juvenile tambaqui is a freshwater omnivorous fish (trophic level of 2.0) feeding predominantly on vegetable ingredients in its natural habitat, including algae, fruit or seeds (van der Meer et al., 1996), with variable dietary content of $n-6 / n-3$ ratio, EPA and DHA. The present study clearly indicates that EFA requirements of tambaqui can be satisfied by C18 PUFA, as no growth depression was observed in fish fed VO diets compared to fish fed the FO-based diet (control diet). Similar results have been reported for other freshwater fish (Sargent et al., 2002; Tocher, 2010).

The growth performance of tambaqui juveniles in this study was within the range of growth responses obtained in other studies with this species (DGI ranging from 2.9 to 4.9) (Silva et al., 2007; van der Meer et al., 1996; de Almeida et al., 2011). Moreover, growth performance of tambaqui was not affected by the increase of dietary LNA/ALA, which ranged between extreme values of 3.1 to 26.9. The effect of dietary

Table 5

Plasma metabolites $\left(\mathrm{mg} \mathrm{L}^{-1}\right)$ of juvenile Tambaqui fed the experimental diets for 7 weeks.

\begin{tabular}{|c|c|c|c|c|c|c|c|c|c|c|c|c|c|}
\hline & \multirow[t]{2}{*}{ Control } & \multicolumn{6}{|c|}{ Dietary LNA/ALA ratio } & \multirow[t]{2}{*}{ SEM } & \multirow[t]{2}{*}{$P$-value } & \multicolumn{4}{|c|}{ Regression $\left(\mathrm{P}, \mathrm{r}^{2}\right)$} \\
\hline & & 3.1 & 3.8 & 5.0 & 7.2 & 12.0 & 26.9 & & & Linear & & Quadr & \\
\hline Cholesterol & 1279.7 & 1217.6 & 1153.8 & 1138.6 & 1170.4 & 1076.2 & 1168.4 & 18.7 & .127 & 0.776 & 0.023 & 0.191 & 0.669 \\
\hline Triglycerides & 2967.8 & 3002.4 & 3121.6 & 3072.8 & 3536.2 & 3070.0 & 3138.0 & 85.2 & .628 & 0.974 & 0.000 & 0.867 & 0.091 \\
\hline HDL & $98.0^{\mathrm{ab}}$ & $117.7^{\mathrm{b}}$ & $70.8^{\mathrm{a}}$ & $126.4^{\mathrm{b}}$ & $95.0^{\mathrm{ab}}$ & $100.8^{\mathrm{ab}}$ & $107.4^{\mathrm{ab}}$ & 4.1 & .009 & 0.877 & 0.007 & 0.976 & 0.016 \\
\hline LDL & 465.1 & 381.0 & 413.8 & 376.6 & 399.8 & 411.1 & 387.5 & 10.2 & .397 & 0.925 & 0.003 & 0.638 & 0.259 \\
\hline Protein $\left(\mathrm{g} \mathrm{L}^{-1}\right)$ & 51.6 & 51.1 & 52.0 & 52.5 & 51.0 & 50.1 & 50.8 & 0.4 & .682 & 0.310 & 0.252 & 0.340 & 0.512 \\
\hline Glucose & $550.0^{\mathrm{a}}$ & $547.8^{\mathrm{a}}$ & $563.8^{\mathrm{ab}}$ & $601.1^{\mathrm{ab}}$ & $697.8^{\mathrm{b}}$ & $613.3^{\mathrm{ab}}$ & $555.7^{\mathrm{ab}}$ & 13.7 & .023 & 0.750 & 0.028 & 0.378 & 0.477 \\
\hline
\end{tabular}

Values are means of nine fish. SEM is pooled of standard error of mean.

Mean in the same row with different superscript letters are significantly different (ANOVA analysis; $P<.05$ ). Regression analysis excluded the control diet. 
Table 6

Liver fatty acid profile $\left(\mathrm{mg} \mathrm{g}^{-1}\right)$ of juvenile Tambaqui fed the experimental diets for 7 weeks.

\begin{tabular}{|c|c|c|c|c|c|c|c|c|c|c|c|c|c|}
\hline \multirow[b]{3}{*}{ 14:0 } & \multirow{3}{*}{$\begin{array}{l}\text { Control } \\
4.8^{\mathrm{b}}\end{array}$} & \multicolumn{6}{|c|}{ Dietary LNA/ALA ratio } & \multirow{3}{*}{$\begin{array}{c}\text { SEM } \\
0.2\end{array}$} & \multirow{3}{*}{$\begin{array}{l}P \text {-value } \\
.000\end{array}$} & \multicolumn{4}{|c|}{ Regression $\left(\mathrm{P}, \mathrm{r}^{2}\right)$} \\
\hline & & \multirow{2}{*}{$\frac{3.1}{2.5^{\mathrm{a}}}$} & \multirow{2}{*}{$\frac{3.8}{2.5^{\mathrm{a}}}$} & \multirow{2}{*}{$\begin{array}{l}5.0 \\
3.1^{\mathrm{a}}\end{array}$} & \multirow{2}{*}{$\frac{7.2}{3.2^{\mathrm{a}}}$} & \multirow{2}{*}{$\frac{12.0}{2.5^{\mathrm{a}}}$} & \multirow{2}{*}{$\begin{array}{l}26.9 \\
3.5^{\mathrm{ab}}\end{array}$} & & & \multicolumn{2}{|l|}{ Linear } & \multicolumn{2}{|c|}{ Quadratic } \\
\hline & & & & & & & & & & 0.194 & 0.378 & 0.462 & 0.402 \\
\hline $16: 0$ & $191.7^{\mathrm{b}}$ & $156.3^{\mathrm{a}}$ & $162.7^{\mathrm{ab}}$ & $166.4^{\mathrm{ab}}$ & $163.4^{\mathrm{ab}}$ & $162.9^{\mathrm{ab}}$ & $181.0^{\mathrm{ab}}$ & 3.0 & .014 & 0.013 & 0.819 & 0.060 & 0.846 \\
\hline $16: 1$ & $18.0^{\mathrm{b}}$ & $9.8^{\mathrm{a}}$ & $10.5^{\mathrm{a}}$ & $11.5^{\mathrm{a}}$ & $11.0^{\mathrm{a}}$ & $10.6^{\mathrm{a}}$ & $13.0^{\mathrm{a}}$ & 0.5 & .000 & 0.042 & 0.687 & 0.160 & 0.706 \\
\hline $18: 0$ & 166.0 & 171.4 & 165.5 & 160.4 & 171.8 & 164.4 & 160.6 & 1.5 & .223 & 0.290 & 0.271 & 0.620 & 0.273 \\
\hline $18: 1 n-9$ & 245.8 & 222.8 & 248.7 & 235.6 & 234.3 & 236.1 & 250.9 & 3.6 & .414 & 0.217 & 0.348 & 0.503 & 0.367 \\
\hline 18:2n-6 LNA & $51.3^{\mathrm{a}}$ & $87.1^{\mathrm{bc}}$ & $90.4^{\mathrm{c}}$ & $75.3^{\mathrm{b}}$ & $78.9^{\mathrm{bc}}$ & $76.7^{\mathrm{bc}}$ & $74.6^{\mathrm{b}}$ & 1.9 & .000 & 0.198 & 0.373 & 0.286 & 0.566 \\
\hline $18: 3 n-6$ & 0.1 & 0.5 & 0.9 & 0.8 & 0.6 & 0.1 & 1.2 & 0.1 & .243 & 0.061 & 0.627 & 0.199 & 0.659 \\
\hline $20: 1$ & 17.3 & 17.2 & 15.7 & 174 & 18.2 & 17.4 & 17.1 & 0.3 & .535 & 0.852 & 0.010 & 0.661 & 0.241 \\
\hline 18:3n-3 ALA & $0.8^{\mathrm{ab}}$ & $4.0^{c}$ & $3.4^{\mathrm{c}}$ & $2.0^{\mathrm{b}}$ & $1.5^{\mathrm{ab}}$ & $1.1^{\mathrm{ab}}$ & $1.0^{\mathrm{a}}$ & 0.2 & .000 & 0.130 & 0.475 & 0.063 & 0.842 \\
\hline $20: 2$ & $12.6^{\mathrm{a}}$ & $22.4^{\mathrm{b}}$ & $18.7^{\mathrm{b}}$ & $20.3^{\mathrm{b}}$ & $20.3^{\mathrm{b}}$ & $19.5^{\mathrm{b}}$ & $18.3^{\mathrm{b}}$ & 0.6 & .000 & 0.185 & 0.390 & 0.460 & 0.404 \\
\hline $22: 0$ & $1.7^{\mathrm{a}}$ & $3.8^{\mathrm{b}}$ & $3.6^{\mathrm{b}}$ & $4.5^{\mathrm{bc}}$ & $4.4^{\mathrm{bc}}$ & $5.2^{\mathrm{c}}$ & $4.5^{\mathrm{bc}}$ & 0.2 & .000 & 0.380 & 0.195 & 0.062 & 0.844 \\
\hline $20: 3 n-6$ & $16.6^{\mathrm{a}}$ & $50.2^{\mathrm{b}}$ & $45.8^{\mathrm{b}}$ & $46.3^{\mathrm{b}}$ & $45.4^{\mathrm{b}}$ & $44.6^{\mathrm{b}}$ & $43.0^{\mathrm{b}}$ & 1.5 & .000 & 0.089 & 0.556 & 0.172 & 0.691 \\
\hline $20: 4 n-6$ ARA & $30.8^{\mathrm{a}}$ & $77.5^{\mathrm{b}}$ & $75.0^{\mathrm{b}}$ & $90.7^{\mathrm{bc}}$ & $94.9^{\mathrm{bc}}$ & $104.5^{\mathrm{c}}$ & $102.6^{\mathrm{c}}$ & 3.6 & .000 & 0.105 & 0.521 & 0.024 & 0.916 \\
\hline $20: 5 n-3$ EPA & $16.3^{\mathrm{e}}$ & $8.7^{\mathrm{d}}$ & $6.5^{\mathrm{cd}}$ & $4.9^{c}$ & $2.7^{\mathrm{b}}$ & $2.0^{\mathrm{b}}$ & $0.9^{\mathrm{a}}$ & 0.7 & .000 & 0.071 & 0.600 & 0.037 & 0.889 \\
\hline $22: 6 n-3$ DHA & $169.7^{\mathrm{e}}$ & $98.6^{\mathrm{d}}$ & $87.4^{\mathrm{d}}$ & $82.2^{\mathrm{cd}}$ & $64.2^{\mathrm{bc}}$ & $56.6^{\mathrm{b}}$ & $31.3^{\mathrm{a}}$ & 5.5 & .000 & 0.006 & 0.872 & 0.007 & 0.964 \\
\hline $\mathrm{n}-3$ & $186.9^{\mathrm{e}}$ & $113.0^{\mathrm{d}}$ & $97.0^{\mathrm{cd}}$ & $90.6^{c}$ & $69.3^{\mathrm{b}}$ & $60.4^{\mathrm{b}}$ & $33.1^{\mathrm{a}}$ & 6.1 & .000 & 0.010 & 0.842 & 0.010 & 0.954 \\
\hline$n-6$ & $95.6^{\mathrm{a}}$ & $211.6^{\mathrm{bc}}$ & $210.6^{\mathrm{b}}$ & $213.2^{\mathrm{bc}}$ & $219.7^{\mathrm{bc}}$ & $230.1^{\mathrm{bc}}$ & $239.3^{c}$ & 6.2 & .000 & 0.004 & 0.902 & 0.001 & 0.989 \\
\hline$n-6 / n-3$ & $5.1^{\mathrm{a}}$ & $18.2^{\mathrm{b}}$ & $21.7^{\mathrm{bc}}$ & $23.9^{c}$ & $32.1^{\mathrm{d}}$ & $40.0^{\mathrm{e}}$ & $65.3^{f}$ & 2.3 & .000 & 0.000 & 0.983 & 0.000 & 0.995 \\
\hline LNA/ALA & $35.1^{\mathrm{bc}}$ & $22.6^{\mathrm{a}}$ & $23.7^{\mathrm{ab}}$ & $39.1^{\mathrm{cd}}$ & $61.2^{\mathrm{de}}$ & $79.3^{\mathrm{e}}$ & $122.2^{\mathrm{f}}$ & 5.3 & .000 & 0.002 & 0.927 & 0.001 & 0.988 \\
\hline$\Sigma$ SAFA & $366.2^{\mathrm{b}}$ & $332.6^{\mathrm{a}}$ & $335.4^{\mathrm{a}}$ & $338.1^{\mathrm{ab}}$ & $343.5^{\mathrm{ab}}$ & $335.9^{\mathrm{ab}}$ & $342.3^{\mathrm{ab}}$ & 2.9 & .019 & 0.251 & 0.310 & 0.540 & 0.337 \\
\hline$\Sigma$ MUFA & 290.7 & 248.8 & 280.8 & 264.5 & 263.0 & 264.6 & 272.7 & 4.1 & .208 & 0.540 & 0.101 & 0.850 & 0.102 \\
\hline$\Sigma$ PUFA & $285.8^{\mathrm{ab}}$ & $319.0^{\mathrm{b}}$ & $307.6^{\mathrm{ab}}$ & $303.8^{\mathrm{ab}}$ & $289.0^{\text {ab }}$ & $290.5^{\mathrm{ab}}$ & $263.2^{\mathrm{a}}$ & 4.4 & .022 & 0.007 & 0.869 & 0.028 & 0.909 \\
\hline$\Sigma$ LC-PUFA & $233.6^{\mathrm{b}}$ & $234.0^{\mathrm{b}}$ & $221.2^{\mathrm{b}}$ & $225.5^{\mathrm{b}}$ & $207.8^{\mathrm{ab}}$ & $179.1^{\mathrm{a}}$ & $168.4^{\mathrm{a}}$ & 4.7 & .000 & 0.015 & 0.807 & 0.004 & 0.974 \\
\hline
\end{tabular}

Values are means of nine fish. SEM is pooled of standard error of mean.

Mean in the same row with different superscript letters are significantly different (ANOVA analysis; $P<.05$ ). Regression analysis excluded the control diet.

LNA/ALA on growth performance of freshwater species is still controversial, and it seems to be species-specific. While some studies showed no differences on growth performance (Blanchard et al., 2008; Karapanagiotidis et al., 2007; Senadheera et al., 2010; Thanuthong et al., 2011; Tian et al., 2016), other studies observed a growth depression by increasing dietary LNA/ALA ratio (Tan et al., 2009; ElHusseiny et al., 2010; Wu and Chen, 2012). These species differences are most likely linked to an effect of dietary FA balance on bioconversion of PUFA into LC-PUFA, which is dependent on the presence, abundance, and activity of the specific enzymes involved in this elongation-desaturation pathway (Emery et al., 2013).

In the present study, the vegetable oil mix used had different LNA/ ALA ratios and that did not affect feed efficiency, which was high (0.9-1.0). Dietary lipid sources include a variety of vegetable oils and animals fats that have different fatty acids profiles and hence variable LNA/ALA ratios, and this may affect feed utilization by fish. Nonetheless, freshwater fish use efficiently different dietary oil sources (Blanchard et al., 2008; Karapanagiotidis et al., 2007; Senadheera et al.,

Table 7

White muscle fatty acid profile $\left(\mathrm{mg} \mathrm{g}^{-1}\right.$ ) of juvenile Tambaqui fed the experimental diets for 7 weeks.

\begin{tabular}{|c|c|c|c|c|c|c|c|c|c|c|c|c|c|}
\hline & \multirow[t]{2}{*}{ Control } & \multicolumn{6}{|c|}{ LNA/ALA ratio } & \multirow[t]{2}{*}{ SEM } & \multirow[t]{2}{*}{$P$-value } & \multicolumn{4}{|c|}{ Regression $\left(\mathrm{P}, \mathrm{r}^{2}\right)$} \\
\hline & & 3.1 & 3.8 & 5.0 & 7.2 & 12.0 & 26.9 & & & Linear & & Quadrat & \\
\hline $14: 0$ & $11.0^{\mathrm{a}}$ & $5.1^{\mathrm{b}}$ & $4.3^{\mathrm{b}}$ & $4.1^{\mathrm{b}}$ & $5.3^{\mathrm{b}}$ & $5.1^{\mathrm{b}}$ & $4.6^{\mathrm{b}}$ & 0.4 & .000 & 0.985 & 0.000 & 0.764 & 0.164 \\
\hline $16: 0$ & $213.5^{\mathrm{b}}$ & $197.3^{\mathrm{ab}}$ & $191.3^{\mathrm{ab}}$ & $188.8^{\mathrm{a}}$ & $209.5^{\mathrm{ab}}$ & $198.3^{\mathrm{ab}}$ & $195.1^{\mathrm{ab}}$ & 2.2 & .009 & 0.958 & 0.001 & 0.721 & 0.196 \\
\hline $16: 1$ & $33.1^{c}$ & $22.8^{\mathrm{ab}}$ & $19.4^{\mathrm{ab}}$ & $18.2^{\mathrm{a}}$ & $26.2^{\mathrm{bc}}$ & $21.4^{\mathrm{ab}}$ & $19.8^{\mathrm{ab}}$ & 0.9 & .000 & 0.760 & 0.026 & 0.813 & 0.129 \\
\hline $18: 0$ & 100.2 & 97.2 & 103.5 & 104.5 & 97.6 & 99.1 & 100.7 & 1.0 & .457 & 0.926 & 0.002 & 0.907 & 0.063 \\
\hline $18: 1 n-9$ & $273.8^{\mathrm{a}}$ & $317.7^{\mathrm{ab}}$ & $289.9^{\mathrm{ab}}$ & $276.4^{\mathrm{a}}$ & $328.3^{\mathrm{b}}$ & $317.2^{\mathrm{ab}}$ & $320.2^{\mathrm{ab}}$ & 5.0 & .002 & 0.425 & 0.164 & 0.675 & 0.230 \\
\hline 18:2n-6 LNA & $104.9^{\mathrm{a}}$ & $175.0^{\mathrm{b}}$ & $189.1^{\mathrm{b}}$ & $177.0^{\mathrm{b}}$ & $184.1^{\mathrm{b}}$ & $188.4^{\mathrm{b}}$ & $184.6^{\mathrm{b}}$ & 4.2 & .000 & 0.543 & 0.099 & 0.586 & 0.300 \\
\hline $18: 3 n-6$ & $0.8^{\mathrm{a}}$ & $2.3^{\mathrm{bc}}$ & $2.1^{\mathrm{bc}}$ & $2.0^{\mathrm{b}}$ & $2.7^{\mathrm{bc}}$ & $2.8^{\mathrm{bc}}$ & $2.9^{c}$ & 0.1 & .000 & 0.112 & 0.508 & 0.175 & 0.687 \\
\hline $20: 1$ & $8.6^{\mathrm{b}}$ & $6.9^{\mathrm{a}}$ & $8.1^{\mathrm{ab}}$ & $8.3^{\mathrm{b}}$ & $8.3^{\mathrm{b}}$ & $8.4^{\mathrm{b}}$ & $8.8^{\mathrm{b}}$ & 0.1 & .001 & 0.151 & 0.440 & 0.281 & 0.571 \\
\hline 18:3n-3ALA & $5.7^{\mathrm{ab}}$ & $32.3^{\mathrm{e}}$ & $25.3^{\text {de }}$ & $17.8^{\mathrm{cd}}$ & $14.0^{\mathrm{c}}$ & $11.0^{\mathrm{bc}}$ & $4.5^{\mathrm{a}}$ & 1.4 & .000 & 0.042 & 0.684 & 0.042 & 0.879 \\
\hline $20: 2$ & 6.8 & 7.1 & 8.2 & 9.2 & 7.3 & 7.7 & 7.0 & 0.2 & .073 & 0.367 & 0.205 & 0.697 & 0.214 \\
\hline $22: 0$ & 2.7 & 2.7 & 2.7 & 3.5 & 2.8 & 3.4 & 2.7 & 0.2 & .760 & 0.843 & 0.011 & 0.519 & 0.354 \\
\hline $20: 3 n-6$ & $10.6^{\mathrm{a}}$ & $13.5^{\mathrm{ab}}$ & $19.3^{\mathrm{bc}}$ & $22.5^{\mathrm{c}}$ & $14.6^{\mathrm{ab}}$ & $18.5^{\mathrm{bc}}$ & $17.6^{\mathrm{bc}}$ & 0.8 & .000 & 0.956 & 0.001 & 0.983 & 0.011 \\
\hline $20: 4 n-6$ ARA & $23.6^{\mathrm{ab}}$ & $19.5^{\mathrm{a}}$ & $28.1^{\mathrm{ab}}$ & $35.5^{\mathrm{b}}$ & $24.7^{\mathrm{ab}}$ & $32.0^{\mathrm{ab}}$ & $28.8^{\mathrm{ab}}$ & 1.5 & .049 & 0.698 & 0.042 & 0.733 & 0.187 \\
\hline $22: 2$ & $1.8^{\mathrm{e}}$ & $1.9^{\mathrm{e}}$ & $1.5^{\mathrm{de}}$ & $1.1^{\mathrm{cd}}$ & $1.0^{\mathrm{bc}}$ & $0.6^{\mathrm{b}}$ & $0.2^{\mathrm{a}}$ & 0.1 & .000 & 0.029 & 0.736 & 0.031 & 0.902 \\
\hline 20:5n-3 EPA & $21.1^{\mathrm{d}}$ & $4.4^{\mathrm{c}}$ & $4.3^{b c}$ & $3.8^{\mathrm{c}}$ & $2.0^{\mathrm{abc}}$ & $2.0^{\mathrm{ab}}$ & $1.4^{\mathrm{a}}$ & 1.0 & .000 & 0.054 & 0.646 & 0.038 & 0.887 \\
\hline $22: 6 n-3$ DHA & $75.3^{c}$ & $16.7^{\mathrm{ab}}$ & $20.7^{\mathrm{ab}}$ & $22.2^{\mathrm{b}}$ & $15.7^{\mathrm{ab}}$ & $13.3^{\mathrm{ab}}$ & $9.5^{\mathrm{a}}$ & 3.3 & .000 & 0.035 & 0.712 & 0.127 & 0.747 \\
\hline$n-3$ & $102.6^{\mathrm{d}}$ & $57.6^{\mathrm{c}}$ & $53.4^{c}$ & $44.9^{c}$ & $30.6^{\mathrm{b}}$ & $24.5^{\mathrm{ab}}$ & $18.4^{\mathrm{a}}$ & 4.1 & .000 & 0.041 & 0.687 & 0.009 & 0.956 \\
\hline$n-6$ & $139.6^{\mathrm{a}}$ & $211.9^{\mathrm{b}}$ & $240.7^{\mathrm{b}}$ & $236.7^{\mathrm{b}}$ & $225.8^{\mathrm{b}}$ & $241.7^{\mathrm{b}}$ & $240.5^{\mathrm{b}}$ & 5.5 & .000 & 0.365 & 0.207 & 0.577 & 0.307 \\
\hline$n-6 / n-3$ & $1.4^{\mathrm{a}}$ & $3.9^{\mathrm{b}}$ & $4.6^{\mathrm{bc}}$ & $5.3^{c}$ & $7.8^{\mathrm{d}}$ & $9.5^{\mathrm{d}}$ & $15.2^{\mathrm{e}}$ & 0.6 & .000 & 0.000 & 0.967 & 0.001 & 0.992 \\
\hline LNA/ALA & $18.8^{\mathrm{c}}$ & $5.5^{\mathrm{a}}$ & $7.2^{\mathrm{a}}$ & $10.2^{\mathrm{b}}$ & $13.3^{\mathrm{b}}$ & $18.2^{\mathrm{c}}$ & $44.0^{\mathrm{d}}$ & 1.8 & .000 & 0.000 & 0.994 & 0.000 & 0.995 \\
\hline$\Sigma$ SAFA & $327.9^{\mathrm{b}}$ & $305.7^{\mathrm{ab}}$ & $302.5^{\mathrm{ab}}$ & $302.3^{\mathrm{a}}$ & $319.2^{\mathrm{ab}}$ & $307.2^{\mathrm{ab}}$ & $308.8^{\mathrm{ab}}$ & 2.2 & .005 & 0.691 & 0.044 & 0.741 & 0.181 \\
\hline$\Sigma$ MUFA & 316.0 & 338.2 & 317.3 & 309.4 & 353.5 & 347.0 & 336.9 & 5.3 & .040 & 0.588 & 0.080 & 0.560 & 0.321 \\
\hline$\Sigma$ PUFA & $517.8^{\mathrm{a}}$ & $595.2^{\mathrm{b}}$ & $588.5^{\mathrm{b}}$ & $559.0^{\mathrm{b}}$ & $581.2^{\mathrm{b}}$ & $586.3^{\mathrm{b}}$ & $567.4^{\mathrm{b}}$ & 4.6 & .000 & 0.418 & 0.165 & 0.752 & 0.173 \\
\hline$\Sigma$ LC-PUFA & $140.7^{\mathrm{a}}$ & $55.1^{\mathrm{b}}$ & $71.3^{\mathrm{b}}$ & $79.2^{\mathrm{b}}$ & $66.6^{\mathrm{b}}$ & $65.8^{\mathrm{b}}$ & $58.4^{\mathrm{b}}$ & 4.6 & .000 & 0.440 & 0.155 & 0.695 & 0.215 \\
\hline
\end{tabular}

Mean in the same row with different superscript letters are significantly different (ANOVA analysis; $P<.05$ ). Regression analysis excluded the control diet. 


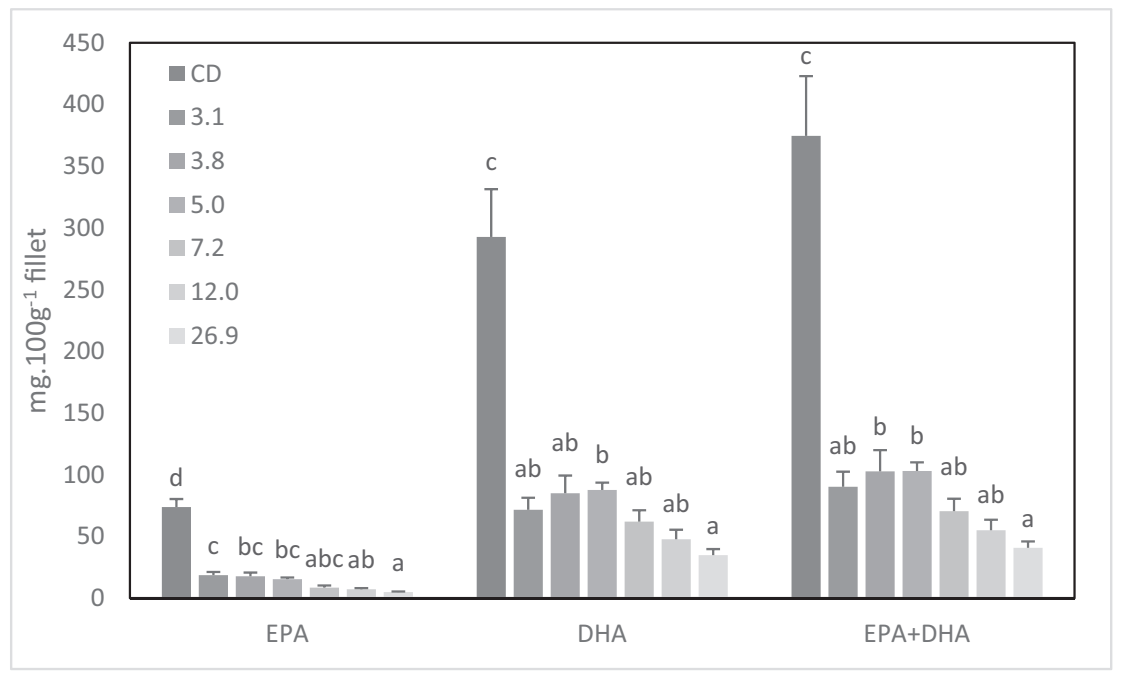

Fig. 1. Muscle EPA and DHA content (mg $100 \mathrm{mg}^{-1}$ muscle) in juvenile tambaqui fed the experimental diets for 7 weeks. Values are means \pm standard error of mean.

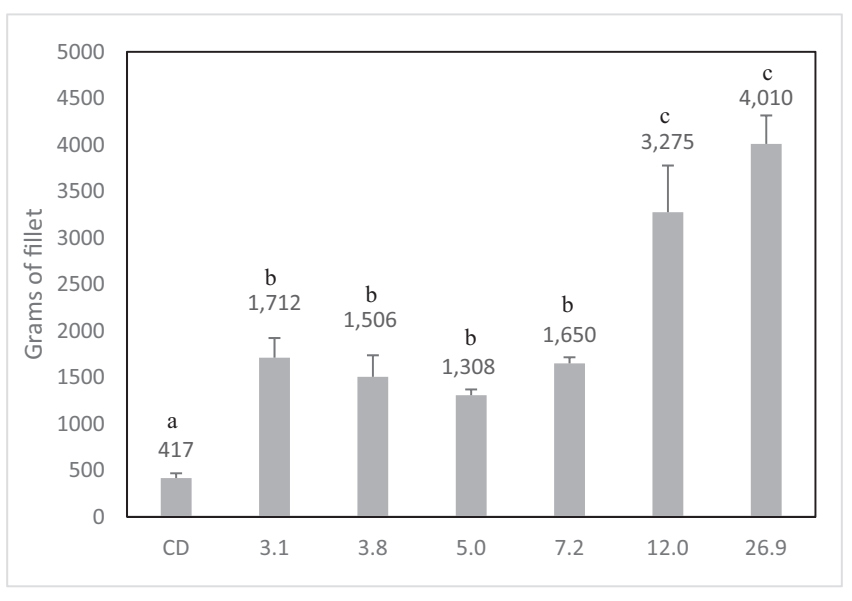

Fig. 2. Recommendations of Tambaqui fillet consumption to meet the requirements $1.4 \mathrm{~g}$ of EPA + DHA per week ( $200 \mathrm{mg}$ daily). Values are means \pm standard error of mean.

2010; Thanuthong et al., 2011; Tian et al., 2016). Considering that different fruits are present in the natural diet of tambaqui, this species seems to be well adapted to a variety of dietary oil sources and dietary FA profiles.

Fish fed the control and 3.1 LNA/ALA diets had lower carcass protein content. There are conflicting reports concerning the effects of FO substitution by other lipid sources on carcass composition. For instance, brown trout showed no differences on carcass protein when fed FO or linseed oil diets (Turchini et al., 2003) and whole-body and muscle proximate composition were also similar in Pacific threadfin (Polydactylus sexfilis) fed diets with pollock oil, soybean oil or a mixture of both oils (Deng et al., 2014). On the contrary, and in agreement with our results, Atlantic salmon and Chinese sturgeon fed vegetable oilbased diets had lower protein content than fish fed FO-based diets (Bell et al., 2002; Wu et al., 2014). Thus, further studies are needed to explain the effect of dietary oil sources on body protein deposition.

In the present study, no differences were observed on plasma cholesterol, LDL, HDL (except for a one-off difference) or triglycerides levels, independently of diets being VO- or FO-based. The transport of FA and other lipid-soluble components to peripheral tissues is predominantly mediated by lipoproteins (Tocher and Glencross, 2015) and dietary FA composition has been reported to affect plasma lipoprotein composition in different fish species (Caballero et al., 2006; Ferreira et al., 2011; Jordal et al., 2007; Torstensen et al., 2000, 2004). For instance, saturated FA were reported to increase plasma cholesterol levels (Gody and Denke, 1990). In this study, saturated FA were similar among VO diets and were almost half of the value of the control diet ( $17 \%$ vs. $32 \%)$, and even though plasma cholesterol level was unaffected. VO contain phytosterols, which can induce a decrease in total cholesterol and LDL by decreasing the intestinal cholesterol absorption (Gilman et al., 2003). Replacement of FO by VO increased circulating HDL in European sea bass (Castro et al., 2016). According to Geay et al. (2011), VO induces gene expression of liver LPL and apolipoproteins ApoA1, the major protein constituent of HDL, thus increasing HDL level. On the contrary, replacing $75 \%$ of FO by rapeseed oil in salmon decreased plasma HDL (Torstensen et al., 2004). The lack of differences in plasma parameters observed in this study may be related, at least in part, to the similar amounts of SAFA, MUFA, and PUFA of all diets, except the control diet. The major difference among VO diets was on the n-3 FA levels that ranged from 1.8 to $13.4 \%$ of total FA.

Lower plasma glucose levels were observed in fish fed the control and 3.1 LNA/ALA diets. Further, the lowest glucose muscle content was observed in fish fed the 26.9 LNA/ALA diet. Though no clear conclusions can be draw from it, these results seem to indicate a poorer glucose uptake and lower insulin sensitivity in fish fed diets with increased dietary LNA levels. Indeed, it is known that insulin sensitivity may be modified in function of dietary FA composition. Several studies demonstrated differential impairment in the degree of insulin sensitivity after feeding with SFA, n-6 PUFA or n-3 PUFA (Storlien et al., 1987; Jucker et al., 1999; Ghafoorunissa et al., 2005). Ghafoorunissa et al. (2005) demonstrated that substituting one third of dietary LNA with ALA, lowering LNA/ALA ratios, significantly improved insulin sensitivity in sucrose-induced insulin resistance (IR) rats, without affecting plasma glucose levels. Further, FO improved glucose utilization and normalized glucose homeostasis in rats (D'Alessandro et al., 2008; AlAmoudi and Abu Araki, 2013).

In salmonids, liver and intestine have relatively higher desaturase and elongase activities than other tissues (Tocher et al., 2006). Also in tambaqui the liver FA profile indicates that it is a very active organ involved in FA metabolism. Indeed, even though dietary LC-PUFA were presented only in the FO-based diet (control diet), liver presented high amounts of EPA, DHA and ARA. In fish fed the VO-based diets liver ARA increased while LNA acid decreased as dietary LNA/ALA ratio increased. Such results are consistent with other studies (Tan et al., 2009; Wu and Chen, 2012; Tian et al., 2016). On the other hand, liver $\mathrm{EPA}+\mathrm{DHA}$ increased as dietary LNA/ALA ratio decreased, while liver ALA was residual. This clearly indicates that tambaqui is able to elongate and desaturate LNA and ALA to LC-PUFA, and that EFA requirements can be satisfied by 18C-PUFA, as in other freshwater fish (Sargent et al., 2002; Ruyter et al., 2006; Turchini et al., 2006; Blanchard et al., 2008, Tan et al., 2009, Tian et al., 2016). Interestingly, 
the VO-based diets dietary lipids contained $42-48 \%$ n-6 FA and $2-13 \%$ n-3 FA, while in the liver these proportions were $21-24 \%$ and $3-11 \%$, respectively. This strong reduction of n-6 FA in the liver, compared to the diets, suggest a different use of FA for metabolism, with higher mobilization of n- 6 FA and conservation of n-3 FA.

Muscle lipids of fish fed the VO-based diets presented a proportion of n-6 FA not very different from that observed in the liver, but n-3 FA were almost half the value found in the liver. The individual FA profile was also different. EPA, DHA and ARA levels were much lower in the muscle than in the liver, while the opposite was true for LNA and ALA levels. Nevertheless, the muscle FA profile was less affected by diet composition than that of the liver FA profile. Further, while in the liver LNA and ARA levels were of the same magnitude, in the muscle LNA levels were circa 5-fold higher than ARA. This suggests that LNA deposition in the muscle is more independent of dietary FA profile than that of liver, as reported by other authors (Francis et al., 2009; Trushenski et al., 2008).

The health benefits for humans of consuming n-3 LC-PUFA are well known (Calder, 2014). In this study it was shown that it would suffice to consume circa $400 \mathrm{~g}$ tambaqui fillets fed a FO-based diet to meet the weekly recommendations of $1400 \mathrm{mg}$ of EPA + DHA per week (FAO, 2010). None of the VO-based diets promoted a deposition of $\mathrm{EPA}+\mathrm{DHA}$ close to that of fish fed the FO-based diet, and the highest deposition of EPA + DHA in the fillet was obtained with a diet with a 5.0 LNA/ALA. Muscle EPA deposition linearly decreased up to 9.6 LNA/ ALA ratio and then stabilized, while DHA and ALA decreased linearly with the increase of dietary LNA/ALA. In this case, however, it would be necessary to consume 3-times more fillets to meet EPA + DHA recommendations.

In conclusion, results of this study confirm that tambaqui possess the ability of elongating and desaturating LNA and ALA to their corresponding end products (ARA, EPA and DHA), as generally observed in other freshwater fish. Dietary LNA/ALA ratios do not seem to affect fish performance, but affect FA metabolism and deposition in fillets. The results of this study also highlight the importance of dietary LNA/ALA ratio from a human consumer's perspective. The dietary LNA/ALA ratio for tambaqui should be around 3.9 to 5.6 to provide the highest EPA, DHA and ARA fillet contents, thus producing the best quality tambaqui fillets for human consumption.

\section{Acknowledgements}

This work was supported by Conselho Nacional de Desenvolvimento Científico e Tecnológico (140740/2013-9) (CNPq) and Coordenação de Aperfeiçoamento de Pessoal de Nível Superior (99999.010687/201409) (CAPES). We also thank the Fundação de Amparo à Pesquisa de Minas Gerais, FAPEMIG, for the research funding granted to Priscila Vieira Rosa (PPM 00227/12) and the Ph.D. scholarship from CNPq, granted to Renan R. Paulino (No. 140740/2013-9), which made possible the accomplishment of this work. We thank the Centro de Aquicultura of Univ. Estadual Paulista, which provided the juvenile fish. We would also like to thank NAQUA staff and Eleci Pereira for their assistance during the experiments.

\section{References}

Al-Amoudi, N.S., Abu Araki, H.A., 2013. Evaluation of vegetable and fish oils diets for the amelioration of diabetes side effects. J. Diabetes Metab. Disord. 12, 13.

de Almeida, L.C., Avilez, I.M., Honorato, C.A., Hori, T.S.F., Moraes, G., 2011. Growth and metabolic responses of tambaqui (Colossoma macropomum) fed different levels of protein and lipid. Aquac. Nutr. 17, E253-E262.

Araújo, F.G., Costa, D.V., Machado, M.R.F., Paulino, R.R., Okamura, D., Rosa, P.V., 2017. Dietary oils influence ovary and carcass composition and embryonic development of zebrafish. Aquac. Nutr. 23, 651-661.

Association of Official Analytical Chemists (AOAC), 2005. Official Methods of Analysis of Official Analytical Chemists International, 16th edn. Association of Official Analytical Chemists, Arlington, VA.

Bell, J., Koppe, W., 2010. Lipids in Aquafeeds, Fish Oil Replacement and Alternative Lipid
Sources in Aquaculture Feeds. CRC Press, pp. 21-59.

Bell, J.G., Henderson, R.J., Tocher, D.R., McGhee, F., Dick, J.R., Porter, A., Smullen, R.P., Sargent, J.R., 2002. Substituting fish oil with crude palm oil in the diet of Atlantic salmon (Salmo salar) affects muscle fatty acid composition and hepatic fatty acid metabolism. J. Nutr. 132, 222-230.

Blanchard, G., Makombu, J.G., Kestemont, P., 2008. Influence of different dietary 18:3n3/18:2n-6 ratio on growth performance, fatty acid composition and hepatic ultrastructure in Eurasian perch, Perca fluviatilis. Aquaculture 284, 144-150.

Bradford, M.M., 1976. A rapid and sensitive method for the quantitation of microgram quantities of protein utilizing the principle of protein-dye binding. Anal. Biochem. 72, 248-254.

Caballero, M.J., Gallardo, G., Robaina, L., Montero, D., Fernandez, A., Izquierdo, M., 2006. Vegetable lipid sources affect in vitro biosynthesis of triacylglycerols and phospholipids in the intestine of sea bream (Sparus aurata). Br. J. Nutr. 95, 448-454.

Calder, P.C., 2014. Very long chain omega-3 (n-3) fatty acids and human health. Eur. J. Lipid Sci. Technol. 116, 1280-1300.

Castro, C., Couto, A., Pérez-Jiménez, A., Serra, C.R., Díaz-Rosales, P., Fernandes, R., Corraze, G., Panserat, S., Oliva-Teles, A., 2016. Effects of fish oil replacement by vegetable oil blend on digestive enzymes and tissue histomorphology of European sea bass (Dicentrarchus labrax) juveniles. Fish Physiol. Biochem. 42, 203-217.

D'Alessandro, M.E., Chicco, A., Lombardo, Y.B., 2008. Dietary fish oil reverses lipotoxicity, altered glucose metabolism, and nPKC 8 translocation in the heart of dyslipemic insulin-resistant rats. Metab. Clin. Exp. 57, 911-919.

Deng, D.F., Ju, Z.Y., Dominy, W.G., Conquest, L., Smiley, S., Bechtel, P.J., 2014. Effect of replacing dietary menhaden oil with pollock or soybean oil on muscle fatty acid composition and growth performance of juvenile Pacific threadfin (Polydactylus sexfilis). Aquaculture 422, 91-97.

El-Husseiny, O.M., Abdul-Aziz, G.M., Goda, A., Suloma, A., 2010. Effect of altering linoleic acid and linolenic acid dietary levels and ratios on the performance and tissue fatty acid profiles of Nile tilapia Oreochromis niloticus fry. Aquac. Int. 18, 1105-1119.

Emery, J.A., Hermon, K., Hamid, N.K., Donald, J.A., Turchini, G.M., 2013. Delta-6 desaturase substrate competition: dietary linoleic acid (18:2n-6) has only trivial effects on alpha-linolenic acid (18:3n-3) bioconversion in the teleost rainbow trout. PLoS One 8, e57463.

Ferreira, M.W., de Araujo, F.G., Costa, D.V., Rosa, P.V., Figueiredo, H.C.P., Murgas, L.D.S., 2011. Influence of dietary oil sources on muscle composition and plasma lipoprotein concentrations in Nile tilapia, Oreochromis niloticus. J. World Aquacult. Soc. 42, 24-33.

Folch, J., Lees, M., Sloane-Stanley, G.H., 1957. A simple method for the isolation and purification of total lipids from animal tissues. J. Biol. Chem. 226.

Food and Agriculture Organization of the United Nations, 2010. Fats and fatty acids in human nutrition: report of an expert consultation. In: FAO Food and Nutrition Paper. 91 (Rome).

Francis, D.S., Peters, D.J., Turchini, G.M., 2009. Apparent in vivo Delta-6 desaturase activity, efficiency, and affinity are affected by total dietary C18 PUFA in the freshwater fish murray cod. J. Agric. Food Chem. 57, 4381-4390.

Furuita, H., Hori, K., Suzuki, Sugita, T., Yamamoto, T., 2007. Effect of n-3 and n-6 fatty acids in broodstock diet on reproduction and fatty acid composition of broodstock and eggs in the Japanese eel Anguilla japonica. Aquaculture 267, 55-61.

Geay, F., Ferraresso, S., Zambonino-Infante, J.L., Bargelloni, L., Quentel, C., Vandeputte, M., Kaushik, S., Cahu, C.L., Mazurais, D., 2011. Effects of the total replacement of fish-based diet with plant-based diet on the hepatic transcriptome of two European sea bass (Dicentrarchus labrax) half-sibfamilies showing different growth rates with the plant-based diet. BMC Genomics 12 (522).

Ghafoorunissa, Ibrahim, A., Natarajan, S., 2005. Substituting dietary linoleic acid with $\alpha$ linolenic acid improves insulin sensitivity in sucrose fed rats. Biochim. Biophys. Acta (BBA) Mol. Cell Biol. Lipids 1733, 67-75.

Gilman, C.I., Leusch, F.D., Breckenridge, W.C., MacLatchy, D.L., 2003. Effects of a phytosterol mixture on male fish plasma lipoprotein fractions and testis P450scc activity. Gen. Comp. Endocrinol. 130, 172-184.

Gody, S., Denke, M., 1990. Dietary influences on serum lipids and lipoproteins. J. Lipid Res. 31, 1149-1172.

Harris, W.S., Mozaffarian, D., Lefevre, M., Toner, C.D., Colombo, J., Cunnane, S.C., Holden, J.M., Klurfeld, D.M., Morris, M.C., Whelan, J., 2009. Towards establishing dietary reference intakes for eicosapentaenoic and docosahexaenoic acids. J. Nutr. 139,804 - -819 S

Henderson, R.J., Tocher, D.R., 1987. The lipid composition and biochemistry of freshwater fish. Prog. Lipid Res. 26, 281-347.

Jordal, A.E.O., Lie, O., Torstensen, B.E., 2007. Complete replacement of dietary fish oil with a vegetable oil blend affect liver lipid and plasma lipoprotein levels in Atlantic salmon (Salmo salar L.). Aquac. Nutr. 13, 114-130.

Jucker, B.M., Cline, G.W., Barucci, N., Shulman, G.I., 1999. Differential effects of safflower oil versus fish oil feeding on insulin-stimulated glycogen synthesis, glycolysis, and pyruvate dehydrogenase flux in skeletal muscle: a 13C nuclear magnetic resonance study. Diabetes 48, 134-140.

Karapanagiotidis, I.T., Bell, M.V., Little, D.C., Yakupitiyage, A., 2007. Replacement of dietary fish oils by alpha-linolenic acid-rich oils lowers omega 3 content in tilapia flesh. Lipids 42, 547-559.

van der Meer, M.B., Machiels, M.A.M., Verdegem, M.C.J., 1995. The effect of dietary protein level on growth, protein utilization and body composition of Colossoma macropomum (Cuvier). Aquac. Res. 26, 901-909.

van der Meer, M.B., Huisman, E.A., Verdegem, M.C.J., 1996. Feed consumption, growth and protein utilization of Colossoma macropomum (Cuvier) at different dietary fish meal/soya meal ratios. Aquac. Res. 27, 531-538.

van der Meer, M.B., Faber, R., Zamora, J.E., Verdegem, M.C.J., 1997. Effect of feeding level on feed losses and feed utilization of soya and fish meal diets in Colossoma 
macropomum (Cuvier). Aquac. Res. 28, 391-403.

Ruyter, B., Moya-Falcón, C., Rosenlund, G., Vegusdal, A., 2006. Fat content and morphology of liver and intestine of Atlantic salmon (Salmo salar): effects of temperature and dietary soybean oil. Aquaculture 252, 441-452.

Sargent, J.R., Tocher, D.R., Bell, J.G., 2002. The lipids. In: Halver, J.E., Hardy, R.W. (Eds.), Fish Nutrition, 3rd Edition. Academic Press, pp. 181-257.

Senadheera, S.P.S.D., Turchini, G.M., Thanuthong, T., Francis, D.S., 2010. Effects of dietary $\alpha$-linolenic acid $(18: 3 n-3)$ /linoleic acid $(18: 2 n-6)$ ratio on growth performance, fillet fatty acid profile and finishing efficiency in Murray cod. Aquaculture 309, 222-230.

Silva, C.R., Gomes, L.C., Brandao, F.R., 2007. Effect of feeding rate and frequency on tambaqui (Colossoma macropomum) growth, production and feeding costs during the first growth phase in cages. Aquaculture 264, 135-139.

Sprague, M., Dick, J.R., Tocher, D.R., 2016. Impact of sustainable feeds on omega-3 longchain fatty acid levels in farmed Atlantic salmon, 2006-2015. Sci. Rep. 6, 21892.

Storlien, L.H., Kraegen, E.W., Chisholm, D.J., Ford, G.L., Bruce, D.G., Pascoe, W.S., 1987. Fish oil prevents insulin resistance induced by high-fat feeding in rats. Science 237, 885-888.

Tan, X.Y., Luo, Z., Xie, P., Liu, X.J., 2009. Effect of dietary linolenic acid/linoleic acid ratio on growth performance, hepatic fatty acid profiles and intermediary metabolism of juvenile yellow catfish Pelteobagrus fulvidraco. Aquaculture 296, 96-101.

Thanuthong, T., Francis, D.S., Senadheera, S.D., Jones, P.L., Turchini, G.M., 2011. Fish oil replacement in rainbow trout diets and total dietary PUFA content: I. Effects on feed efficiency, fat deposition and the efficiency of a finishing strategy. Aquaculture 320, $82-90$.

Tian, J.-J., Lei, C.-X., Ji, H., 2016. Influence of dietary linoleic acid (18:2n-6) and $\alpha$ linolenic acid (18:3n-3) ratio on fatty acid composition of different tissues in fresh water fish Songpu mirror carp, Cyprinus carpio. Aquac. Res. 47, 3811-3825.

Tocher, D.R., 2010. Fatty acid requirements in ontogeny of marine and freshwater fish. Aquac. Res. 41, 717-732.

Tocher, D.R., Glencross, B.D., 2015. Lipids and fatty acids. In: Cheng-Sheng, L., Chhorn, L., Delbert-M, G.I., Webster, C.D. (Eds.), Dietary Nutrients, Additives and Fish Health, pp. 47.

Tocher, D.R., Zheng, X., Schlechtriem, C., Hastings, N., Dick, J.R., Teale, A.J., 2006. Highly unsaturated fatty acid synthesis in marine fish: cloning, functional characterization, and nutritional regulation of fatty acyl $\Delta 6$ desaturase of Atlantic cod
(Gadus morhua L.). Lipids 41, 1003-1016.

Torstensen, B.E., Lie, O., Froyland, L., 2000. Lipid metabolism and tissue composition in Atlantic salmon (Salmo salar L.) - effects of capelin oil, palm oil, and oleic acid-enriched sunflower oil as dietary lipid sources. Lipids 35, 653-664.

Torstensen, B.E., Froyland, L., Lie, O., 2004. Replacing dietary fish oil with increasing levels of rapeseed oil and olive oil - effects on Atlantic salmon (Salmo salar L.) tissue and lipoprotein lipid composition and lipogenic enzyme activities. Aquac. Nutr. 10, 175-192.

Trushenski, J.T., Lewis, H.A., Kohler, C.C., 2008. Fatty acid profile of sunshine bass: I Profile change is affected by initial composition and differs among tissues. Lipids 43 , 629-641.

Turchini, G.M., Mentasti, T., Froyland, L., Orban, E., Caprino, F., Moretti, V.M., Valfre, F., 2003. Effects of alternative dietary lipid sources on performance, tissue chemical composition, mitochondrial fatty acid oxidation capabilities and sensory characteristics in brown trout (Salmo trutta L.). Aquaculture 225, 251-267.

Turchini, G.M., Francis, D.S., De Silva, S.S., 2006. Fatty acid metabolism in the freshwater fish Murray cod (Maccullochella peelii peelii) deduced by the whole-body fatty acid balance method. Comp. Biochem. Physiol. B: Biochem. Mol. Biol. 144, 110-118.

Wu, F.C., Chen, H.Y., 2012. Effects of dietary linolenic acid to linoleic acid ratio on growth, tissue fatty acid profile and immune response of the juvenile grouper Epinephelus malabaricus. Aquaculture 324, 111-117.

Wu, F., Liu, W., Wei, Q.W., Wen, H., Jiang, M., Yang, C.G., Tian, J., 2014. Effects of dietary lipid sources on growth performance, carcass composition, and blood parameters of juvenile Chinese sturgeon (Acipenser sinensis Gray, 1835). J. Appl. Ichthyol. 30, 1620-1625.

Zeng, Y.Y., Jiang, W.D., Liu, Y., Wu, P., Zhao, J., Jiang, J., Kuang, S.Y., Tang, L., Tang, W.N., Zhang, Y.A., Zhou, X.Q., Feng, L., 2015. Optimal dietary alpha-linolenic acid/ linoleic acid ratio improved digestive and absorptive capacities and target of rapamycin gene expression of juvenile grass carp (Ctenopharyngodon idellus). Aquac. Nutr. 22, 1251-1266.

Zeng, Y.-Y., Jiang, W.-D., Liu, Y., Wu, P., Zhao, J., Jiang, J., Kuang, S.-Y., Tang, L., Tang, W.-N., Zhang, Y.-A., Zhou, X.-Q., Feng, L., 2016. Dietary alpha-linolenic acid/linoleic acid ratios modulate intestinal immunity, tight junctions, anti-oxidant status and mRNA levels of NF-kB p65, MLCK and Nrf2 in juvenile grass carp (Ctenopharyngodon idella). Fish Shellfish Immunol. 51, 351-364. 